\title{
Localized dissolution of carbon steel used for pipelines under constant cathodic polarization conditions. Initial stages of defect formation
}

\author{
N.A. Gladkikh, M.A. Maleeva,* L.B. Maksaeva, M.A. Petrunin, \\ A.A. Rybkina, T.A. Yurasova, A.I. Marshakov and R.Kh. Zalavutdinov \\ A.N. Frumkin Institute of Physical Chemistry and Electrochemistry, Russian Academy \\ of Sciences, Leninsky pr. 31, 119071 Moscow, Russian Federation \\ *E-mail: marina.maleeva@gmail.com
}

\begin{abstract}
This work is aimed at studying the possibility of initiation and growth of local (pit-like) defects under cathodic polarization, both in neutral and alkaline solutions, as well as the effect of hydrogen on the local dissolution of tube carbon steel and on the defect formation under permanent cathodic polarization conditions. A combination of optical and electrochemical methods of research allowed us to study the kinetics of the initial stages of localized cathodic dissolution of steel in detail. In fact, the initiation of pit-like defects under cathodic polarization of carbon steel in the presence of chloride ions in the electrolyte was observed experimentally. The incubation period of defect formation under various conditions was determined with high accuracy, and the factors affecting the incubation period of defect initiation were determined. It has been shown that the dependence of the density of appearing corrosion defects on the potential passes through a maximum, while the time until the appearance of the first defect decreases as the potential is shifted towards negative values. It has also been shown that the dependence of the density of corrosion defects on the time of the test passes through a maximum, i.e., some of the appearing defects are metastable and stop functioning after a few dozen hours. It has also been found that the increased rate of hydrogen penetration into the metal caused by addition of a metal hydrogen absorption promoter (thiourea) stimulates both the initiation and development of local defects at cathodic potentials. An increase in thiourea concentration, rate of hydrogen penetration into the metal and the amount of hydrogen absorbed by steel results in a shortening of the incubation period, on the one hand, and in an increase in the number of pit-like defects, on the other hand.
\end{abstract}

Key words: localized corrosion, cathodic protection, pitting.

Received: August 6, 2018. Published: December 12, 2018

doi: $\underline{10.17675 / 2305-6894-2018-7-4-14}$

\section{Introduction}

Corrosion is the cause of emergency destruction of metal structures, especially underground and underwater ones, such as water supply systems, gas and oil pipelines, 
underground reservoirs and storage facilities, underwater part of sea and river transport, etc. [1-4].

The most common method of protecting underground structures from corrosion is electrochemical cathodic protection (ECP). All transmission pipelines in our country are protected by ECP as it is regulated by the corresponding normative documents $[5,6]$.

The long-term use of electrochemical protection has proved its efficiency in the suppression of uniform corrosion. However, despite the fact that almost all transmission pipelines are equipped with ECP installations. This is where cases of occurrence and development of such a dangerous type of corrosion attack as stress corrosion cracking (SCC) have become more frequent $[7,8]$.

All reported cases of SCC on underground pipelines in Russia have occurred with the functioning ECP [9-11]. The effect of ECP on the occurrence and development of SCC is currently not clear enough, but, in particular, it is supposed that cathodic polarization of pipe steel may cause pitting-like defects, which are concentrators of annular voltage on the outer wall of high-pressure pipelines and, consequently, initiators of SCC [12]. The occurrence of localized corrosion defects was studied, as a rule, at periodic change in the cathodic potential value, for example, during the cycling of the potential stage [13] or the overlay of sinusoidal AC with the "protective" ECP potentials [14]. However, at constant value of cathodic potential formation of pitting-like defects on steel was observed [15].

However, the pattern of localized dissolution of carbon steel with cathodic potentials has not been studied sufficiently. Nowadays the causes of formation, the kinetics of corrosion defects and the factors affecting the localized dissolution of steel with cathodic potentials are unknown.

In this regard, the aim of this work was to study the features of formation and development of localized pitting-like defects with cathodic polarization at the initial stages, as well as to identify factors affecting their formation and development.

\section{Experimental}

The experimental setup presented in Figure 1 was used for optical and electrochemical measurements. It consists of a potentiostat, a three-electrode cell, a microscope connected to a digital video camera and a computer.

Disk electrodes made of carbon steel St 3 with a working area of $0.28 \mathrm{~cm}^{2}$ pressed into the holder made of polyamide PA- 6 were used as a working electrode. The surface of the samples was polished with abrasive paper and diamond paste ASM 0.5/0 micron POM to obtain a mirror surface with roughness $\mathrm{Ra}=0.1$ microns..

After that, the samples were washed with ethyl alcohol and distilled water and then dried in the air for 30 minutes. The potential of the working electrode was measured with respect to the silver chloride electrode (reference electrode). A platinum plate $0.7 \times 0.6 \mathrm{~cm}$ was used as a counter electrode. The experiments were performed at room temperature. In this work, all the potentials are given with respect to the silver chloride electrode. 


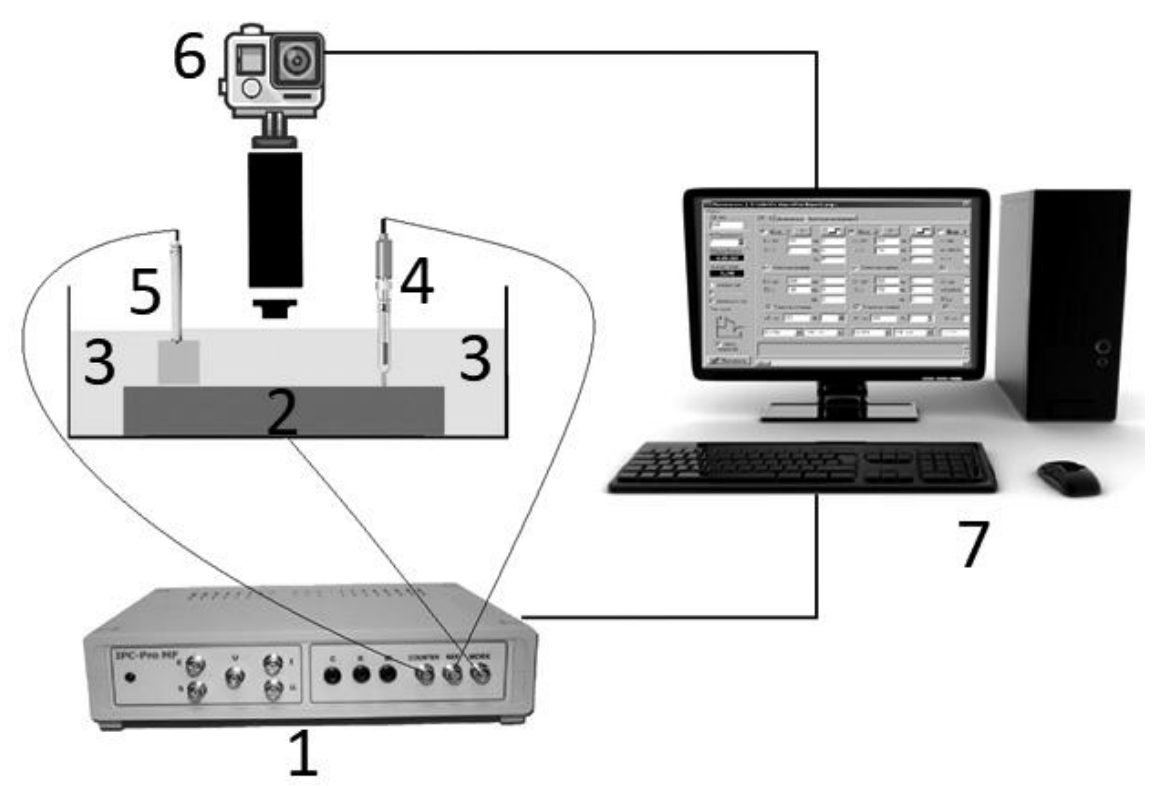

Figure 1. The work cell: 1 - potentiostat, 2 - working electrode, 3 - solution, 4 -reference electrode $(\mathrm{KCl}), 5$ - counter electrode $(\mathrm{Pt}), 6$ - microscope with digital video camera.

Corrosion-electrochemical behavior of iron and low-alloy carbon steels in neutral environment was studied using borate buffer $0.4 \mathrm{M} \mathrm{H}_{3} \mathrm{BO}_{3}+0.1 \mathrm{M} \mathrm{Na}_{2} \mathrm{~B}_{4} \mathrm{O}_{7} \mathrm{pH} 6.7$ as a background solution, because it is shown in the literature that the change in the concentration of borate ions does not affect the kinetics of active metal dissolution [1618]. Chloride ions $(0.1 \mathrm{M} \mathrm{NaCl})$ were added to the background solution, as they can contribute to formation and development of localized dissolution [18].

The following electrolytes were used in the work: background $\mathrm{pH} 6.7$; background + $0.1 \mathrm{M} \mathrm{NaCl} \mathrm{pH} 6.7$.

The thickness of the working solution layer was $1.8 \mathrm{~cm}$ above the electrode. The solution had a natural contact with air. The laboratory reagent grades were used in this work. All the solutions were prepared with distilled water.

Potentiostatic studies were carried out in the range of potentials from -0.8 to $-1.4 \mathrm{~V}$ $v s$. the silver chloride electrode and in a three-electrode electrochemical cell using an PI50-1 potentiostat.

To visualize changes in the metal surface during the experiment, digital image processing was used. It is usually used to process images of the metal surface during its corrosion or anodic dissolution [19,20]. Observation of the processes occurring on the metal surface was carried out using an optical microscope Carton SPZT50 with 200x magnification. A magnified image of the surface area of $1.93 \mathrm{~mm}^{2}$ was recorded throughout the experiment using a digital CMOS camera Amoyca AC-300 connected to the eyepiece via an adapter with 1x magnification. The camera resolution in pixels was $2048 \times 1536$. The data from the camera was transferred to a personal computer and processed in the program ScopePhoto 3.0. 
The images obtained during the experiment allow to extract quantitative information about the kinetics of defects development, their quantity, as well as to establish the exact time of the first defect. During the photo processing, the defects the formation and development of which could be observed during the experiment of 150 hours were taken into account. Thus, the "lifetime" of defects was in the range of $4<t<150$ hours, where 4 hours was the time through which defects were recorded on the surface in all the solutions (except the background). The filling density of defects $\rho$ (quantity) was calculated using the formula (1): $\rho=N / S$, where $N$ is the number of defects in the interval of $4<\tau<150$ hours, $S$ is the visible area of the sample $\left(1.93 \mathrm{~mm}^{2}\right)$.

To obtain kinetic dependencies of the individual defects development, the mean visible defect area $S_{\mathrm{av}}$ was used, which was calculated using the formula: $S_{\mathrm{av}}=\sum s / n$, where $s$ is the the area of individual defect observed during the whole experiment, $n$ is the number of defects recorded in the interval from the first defect formation to the end of the experiment (150 hours).

$\mathrm{X}$-Ray spectrum analysis and photography of the metal surface in secondary electrons were carried out using the microanalyzer Camebax SX50, with $\mathrm{Si}(\mathrm{Li})$ solid-state detector.

\section{Results and discussion}

A study of localized dissolution of carbon steel at cathodic potentials showed that under these conditions of borate buffer the steel behaves steadily. Thus, the formation of localized defects was not recorded after addition to the background solution at $-1.2 \mathrm{~V}$ for 150 hours (Figure 2). However, under the same conditions $(E=-1.2 \mathrm{~V}$, test duration -150 hours), the addition of chloride ions (with concentration $0.1 \mathrm{M}$ ) to the background solution leads to defects on the surface in 5.3 hours (Figure 3a). That's why the localized dissolution of steel was studied in the borate buffer with the addition of chloride ions. The obtained optical images showed the formation of localized defects with the potentials corresponding to the ECP potentials (Figure 3). Thus, defects were registered at constant cathodic polarization in the range of potentials -1.2 to $-1.4 \mathrm{~V}$ (Figures 3a-3c).

In order to make sure that we observe the formation of corrosion defects (not the result of optical distortion) "ex situ" electron microscopic study and X-ray spectrum analysis of the sample surface subjected to cathodic polarization were carried out. In Figure 4a you can see a photograph of the electrode after its addition to the background electrolyte at a constant potential $E=-1.2 \mathrm{~V}$ for 150 hours. As you can see, there are several corrosion defects of the metal surface (marked with numbers 1-4 in the photo). $\mathrm{X}$-Ray spectrum analysis carried out in the field of corrosion defects showed that these defects are formed side by side or in the place of non-metallic impurities, which mainly consist of iron and silicon carbides and oxides. Thus, Figure $4 \mathrm{~b}$ shows the spectrum obtained in the center of defect 4 in Figure 4a. 


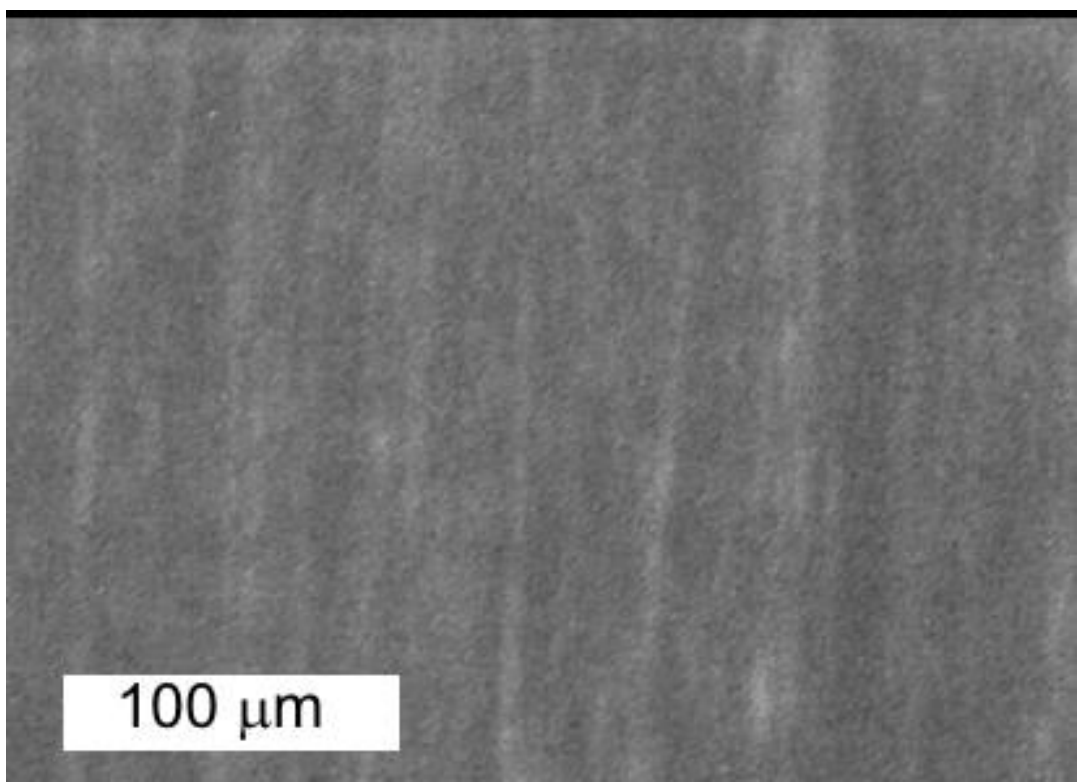

Figure 2. Photograph of sample under a constant cathode potential $E=-1200 \mathrm{mV}, \mathrm{pH} 6.7$, after $150 \mathrm{~min}$ of testing.
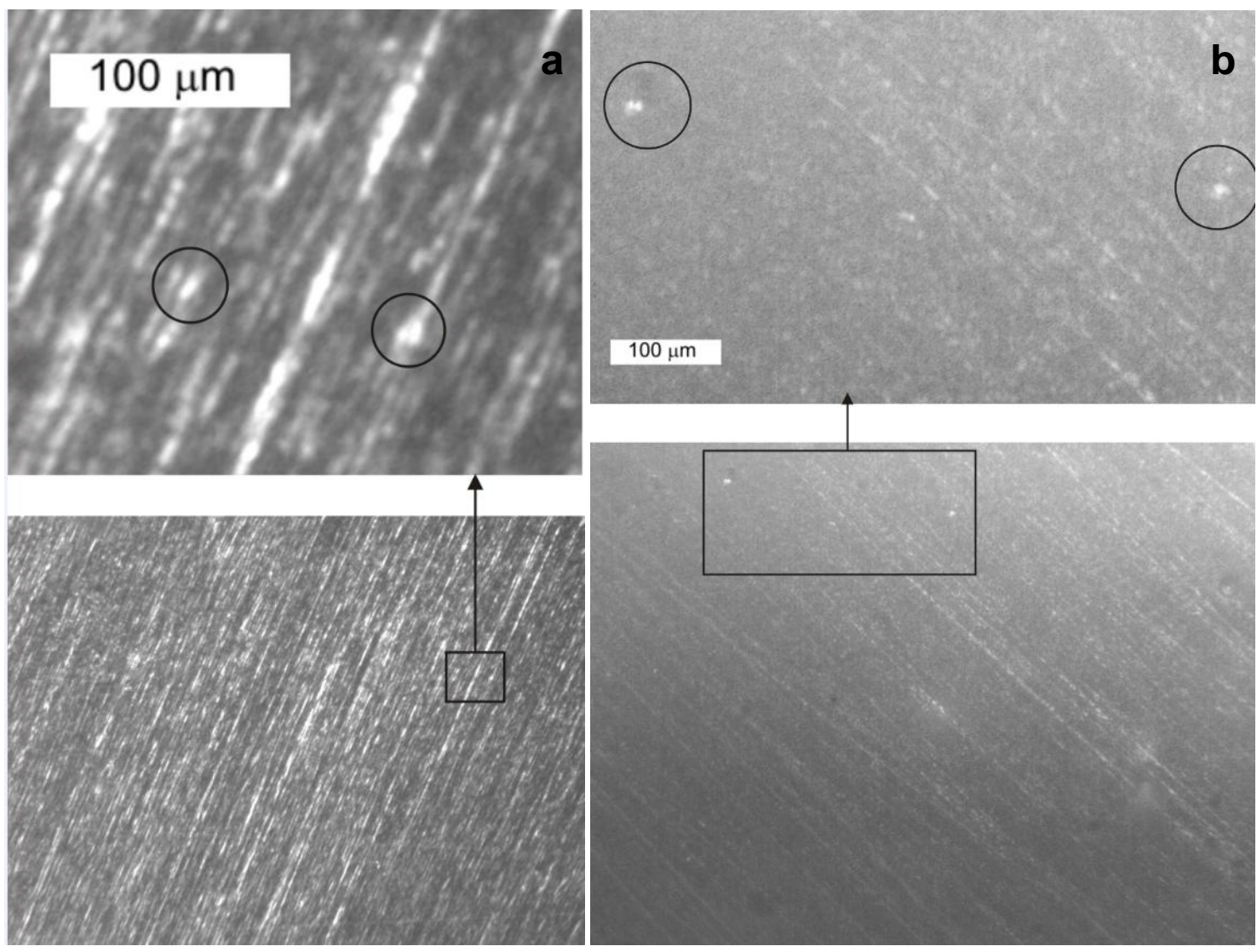


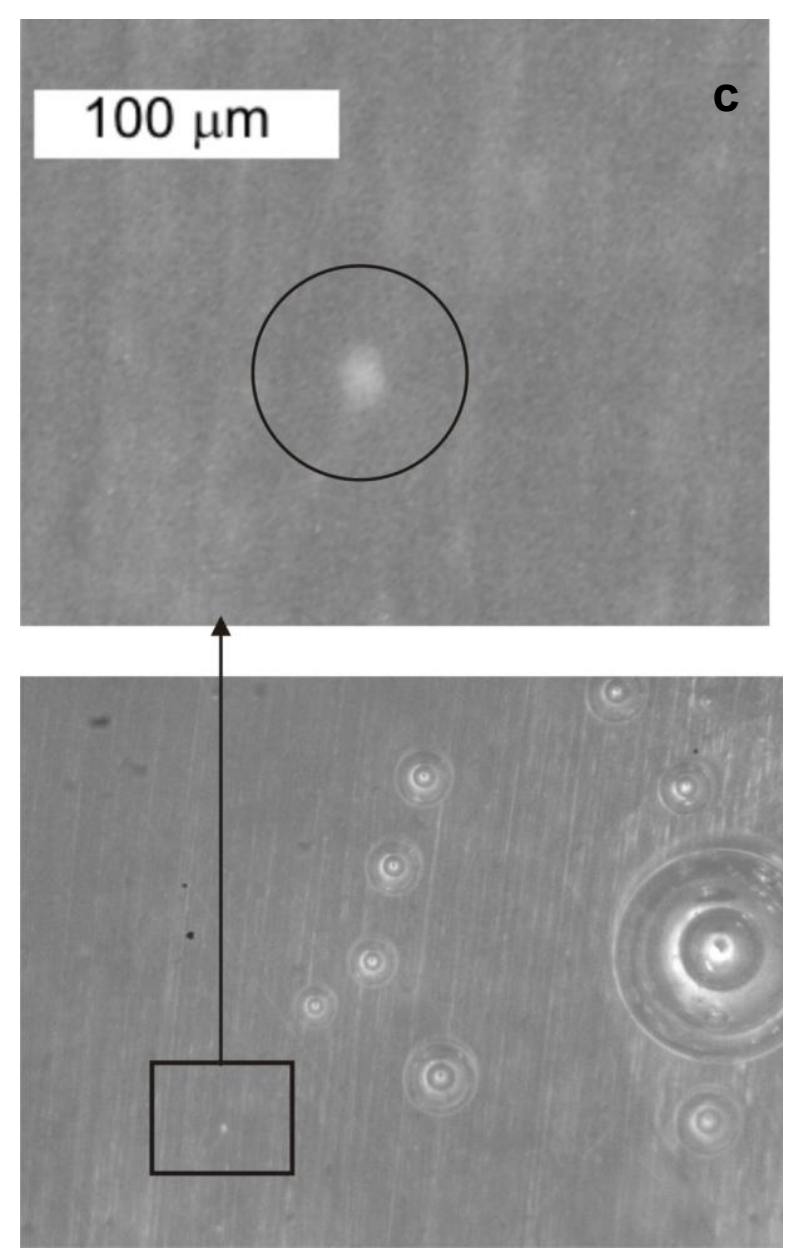

Figure 3. Photographs of samples with constant cathodic polarization, in a background solution + 0.1 M NaCl, pH 6.7: a $-E=-1200 \mathrm{mV} ; \mathrm{b}-E=-1300 \mathrm{mV}$; $-E=-1400 \mathrm{mV}$.

It is obvious that the defects formed at cathodic polarization of metal are not pitting in the classical sense [22], that means the defects caused by the breakdown of the passive barrier film, so we call them pitting-like defects.

Consequently, the process of formation of a pitting-like defect during cathodic polarization (cathodic localized corrosion) should depend on the rates of both cathodic hydrogen extracting and anodic dissolution of the metal, so it is impossible to predict the dependence of the cathodic localized corrosion characteristics on the potential.

In Figure 5 you can see the influence of the cathodic potential value on the number of defects on the steel surface in the background solution during 50 hours. With less negative potentials $(E=-0.8$ to $-0.9 \mathrm{~V})$, the formation of pitting-like defects are also observed. In this range of potentials the formation of defects occurs against the background of uniform dissolution of steel, as with the potential of free steel corrosion in $0.1 \mathrm{M} \mathrm{NaCl}$ solution $(-0.51 \mathrm{~V})$ [23]. However, with cathodic potentials, the number of defects formed per unit surface area (defect density) is much less. When the potential shifts towards the negative direction, the density of defects increases and then decreases. The maximum number of defects is formed with $E=-1.2 \mathrm{~V}$. 

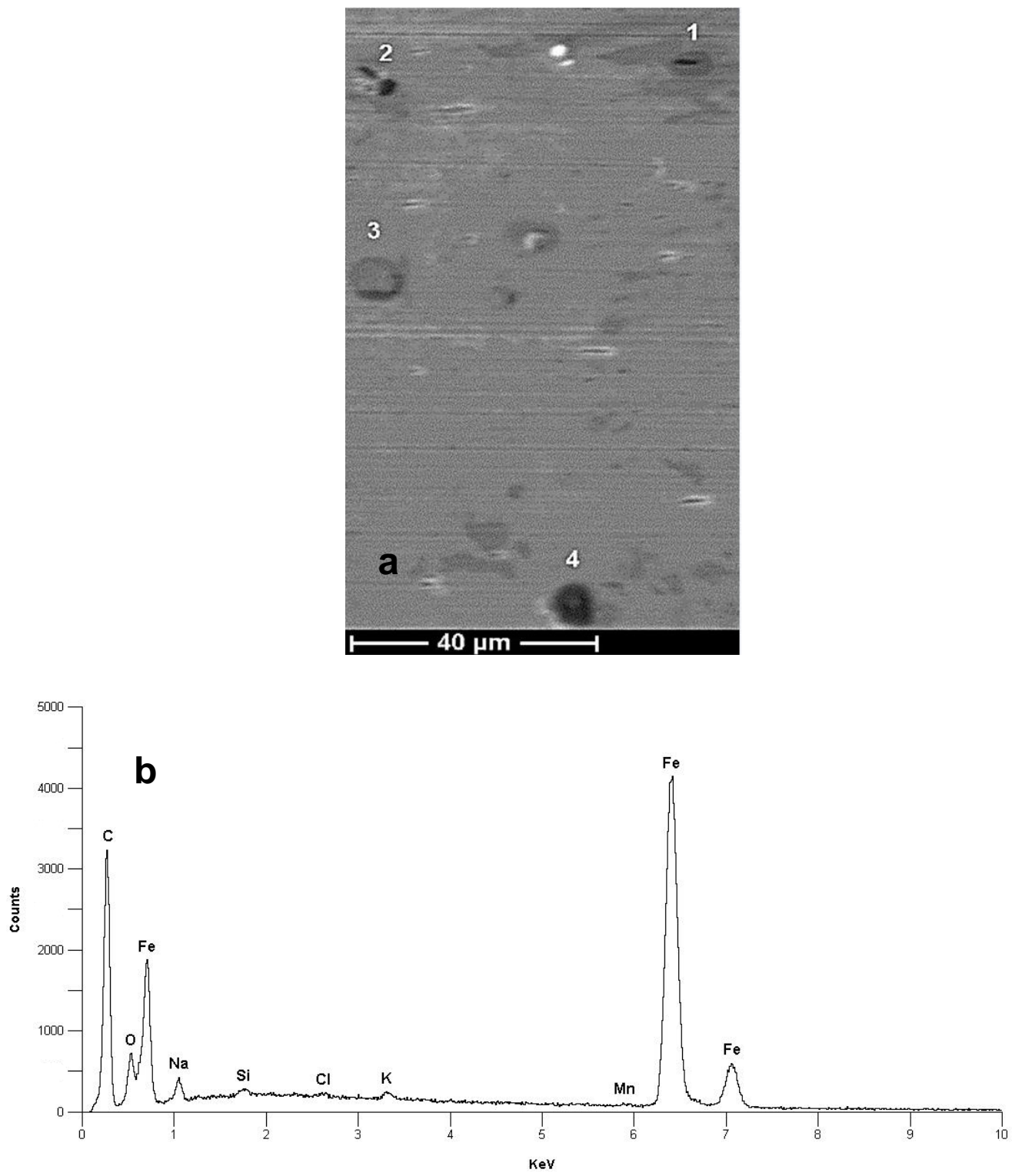

Figure 4. EDX of Steel 3 at $E=-1200 \mathrm{mV}$ in the background electrolyte: a - a photograph of the visible area in "in situ" measurements; b - elemental composition of surface layer at point 4 .

As for kinetics of the individual defects development, during the first few dozens of hours (90 hours) an increase in the visible size of the defects, and then their decrease were observed (Figure 5). If $E=-1.2$ and $-1.3 \mathrm{~V}$, the rapid growth of the defect occurs within the first hour, as well as it was observed with the free corrosion potential [23], then their average size stabilizes and begins to decrease (Figure 6, curves 1 and 2). If $E=-1.4 \mathrm{~V}$, the average defect size increases for about 90 hours, and then it begins to decrease rapidly (Figure 6, curve 3 ). 


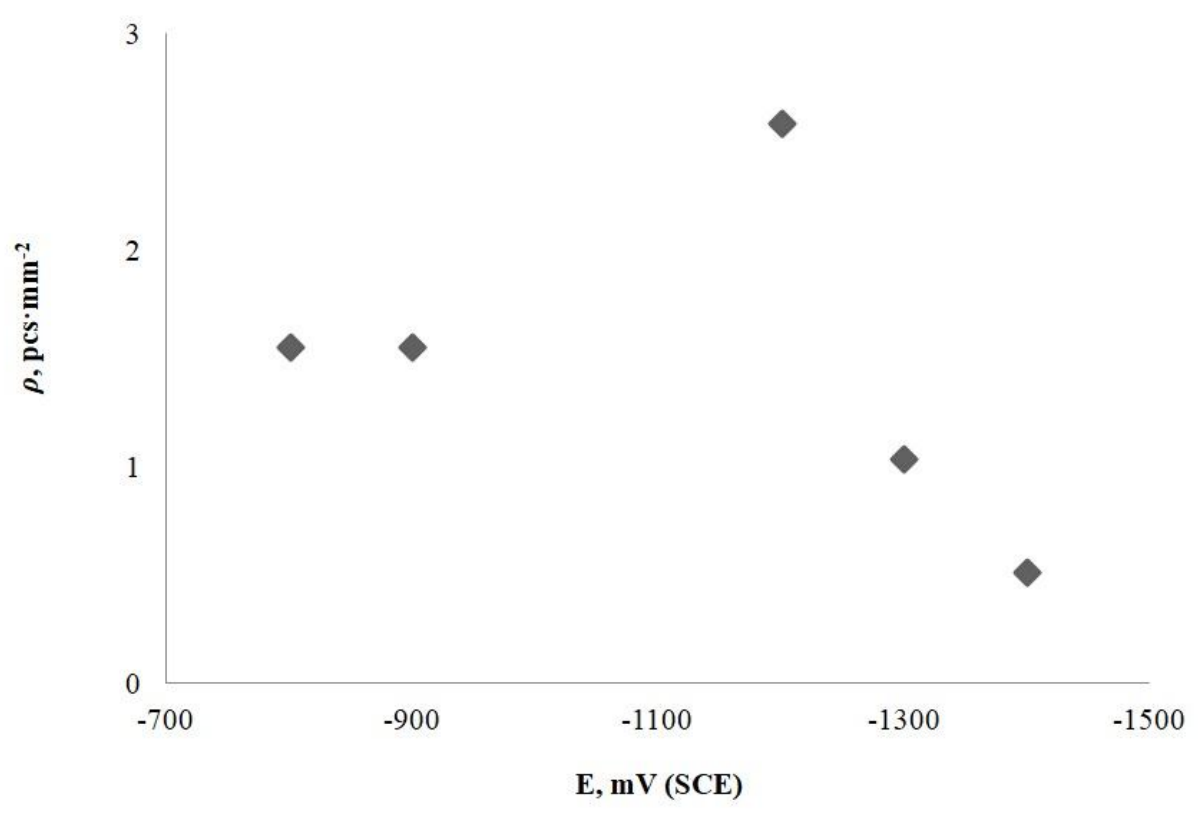

Figure 5. The dependence of $\rho$ on $E$, time $=50$ hours.

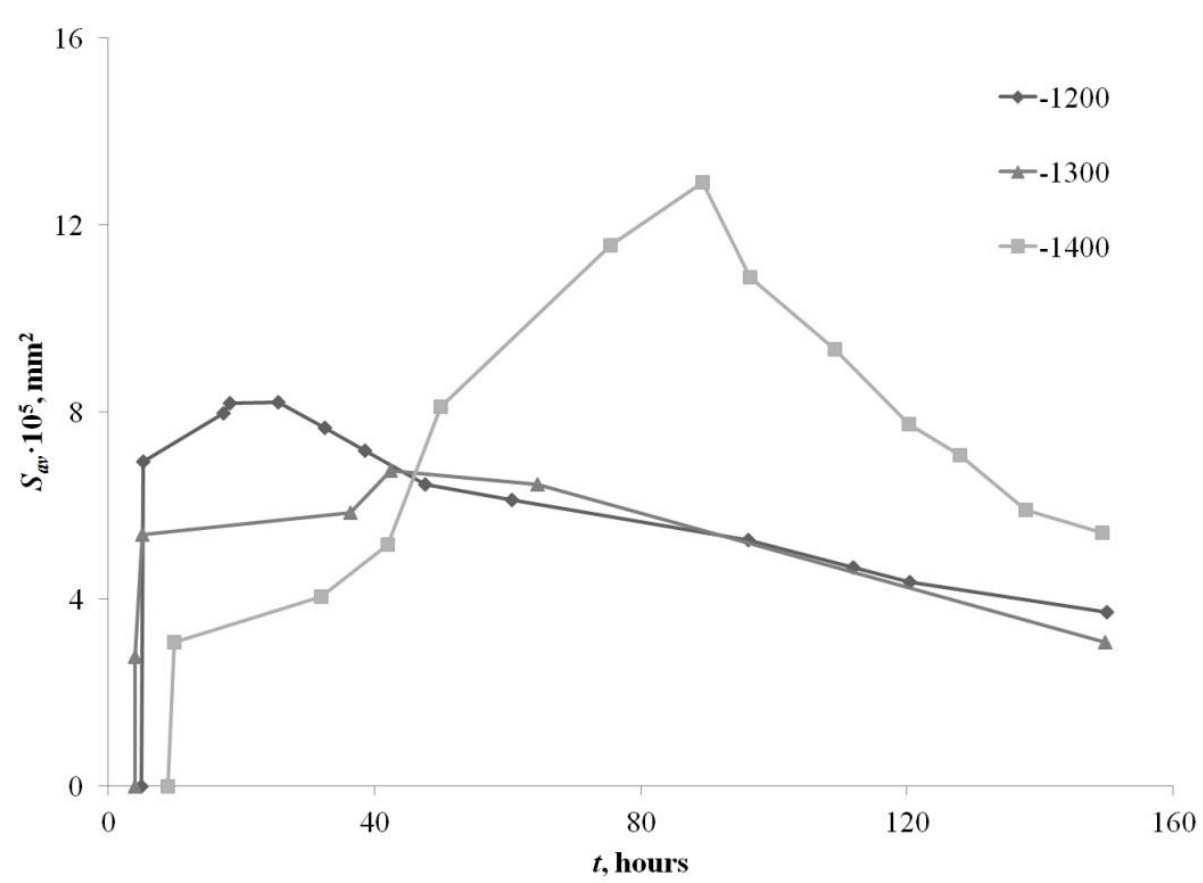

Figure 6. The dependence of the average area of defects on time in the background solution + $0.1 \mathrm{M} \mathrm{NaCl}, \mathrm{pH} 6.7$, at different constant potentials.

It is suggested that the decrease in the mean defect size over time may be connected to the fact that the resulting localized defects are metastable. The confirmation of metastability is a decrease in the number of "working" defects while the experiment duration increases (Figure 7). During the first 90 hours of the experiment, the number of defects does not change, but then their number decreases. 


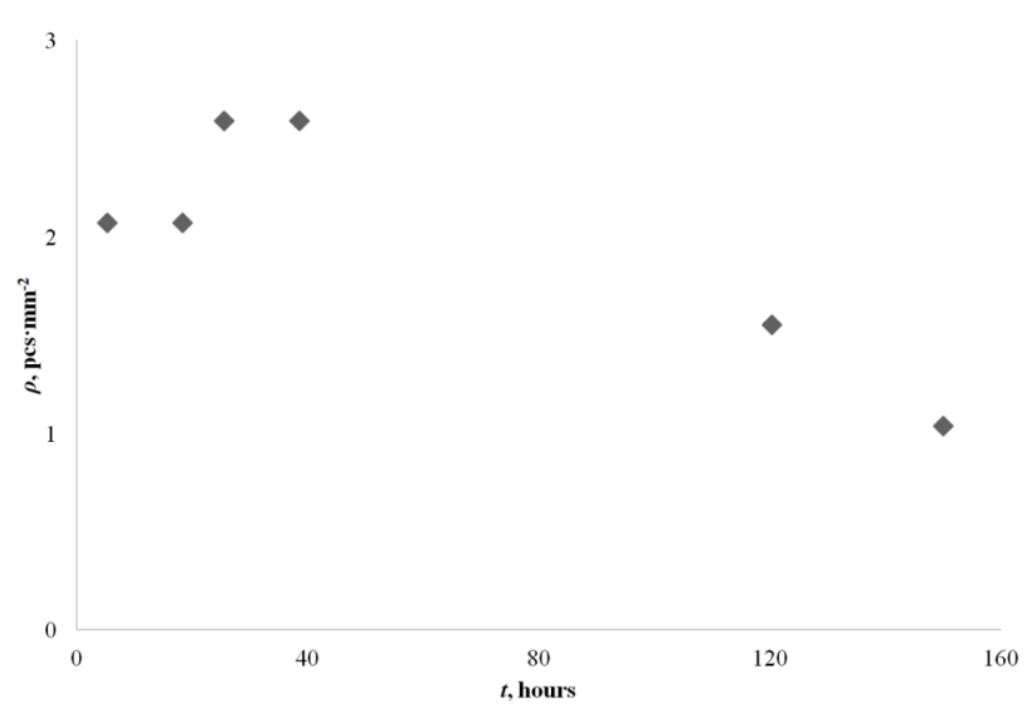

Figure 7. The number of defects as a function of time in the background solution $+0.1 \mathrm{M}$ $\mathrm{NaCl}, \mathrm{pH} 6.7, E=-1200 \mathrm{mV}$.

As for the time before the formation of the first defect, the incubation period is considerably longer with less negative potentials $(E=-0.8$ to $-0.9 \mathrm{~V})$ than with negative potentials (see Table 1). According to the literature data, the decrease in the incubation period of defect formation when the potential shifts towards the cathodic area may be connected to the hydrogen absorption of metals [24-26].

Table 1. The incubation period of the appearance of defects $(I P)$ in a solution of borate buffer, $\mathrm{pH}$ 6.7, with the addition of $0.1 \mathrm{M} \mathrm{NaCl}$ at different potentials.

\begin{tabular}{cccccc}
\hline $\boldsymbol{E}, \mathrm{V}$ & $\mathbf{- 0 . 8}$ & $\mathbf{- 0 . 9}$ & $\mathbf{- 1 . 0}$ & $\mathbf{- 1 . 1}$ & $\mathbf{- 1 . 2}$ \\
\hline$I P, \mathrm{~h}$ & 23.7 & 24.0 & 5.3 & 4.9 & 9.95 \\
\hline
\end{tabular}

As it was suggested, hydrogen added to the metal should influence the formation of localized defects, so the penetration of electrolytic hydrogen into the steel was investigated and the rate of hydrogen penetration was determined in the conditions of our experiment. In Figure 8 you can see the dependence of the rate of hydrogen penetration into the metal on the potential value. You can see that with the potentials -0.8 and $-0.9 \mathrm{~V}$, the hydrogen penetration rate is approximately $2.7 \cdot 10^{-6} \mathrm{~A} / \mathrm{cm}^{2}$ (curve 1 ). When the potentials are shifted towards the cathode area, the rate of hydrogen penetration into the metal increases, but slightly (curve 2). To increase the rate of hydrogen penetration into the metal, the hydrogen absorption promoter - thiourea - was used. As it can be seen in Figure 9, the addition of $10^{-3} \mathrm{M}$ thiourea to the solution (curve 3) significantly increases the penetration of hydrogen into the metal. Increase in the thiourea concentration to $10^{-2} \mathrm{M}$ leads to an increase in the rate of hydrogen penetration by 12 times (curve 4). Thus, the process of formation of defects on the metal surface with an increase in the concentration of thiourea in the solution is more intensive (Figure 9). 


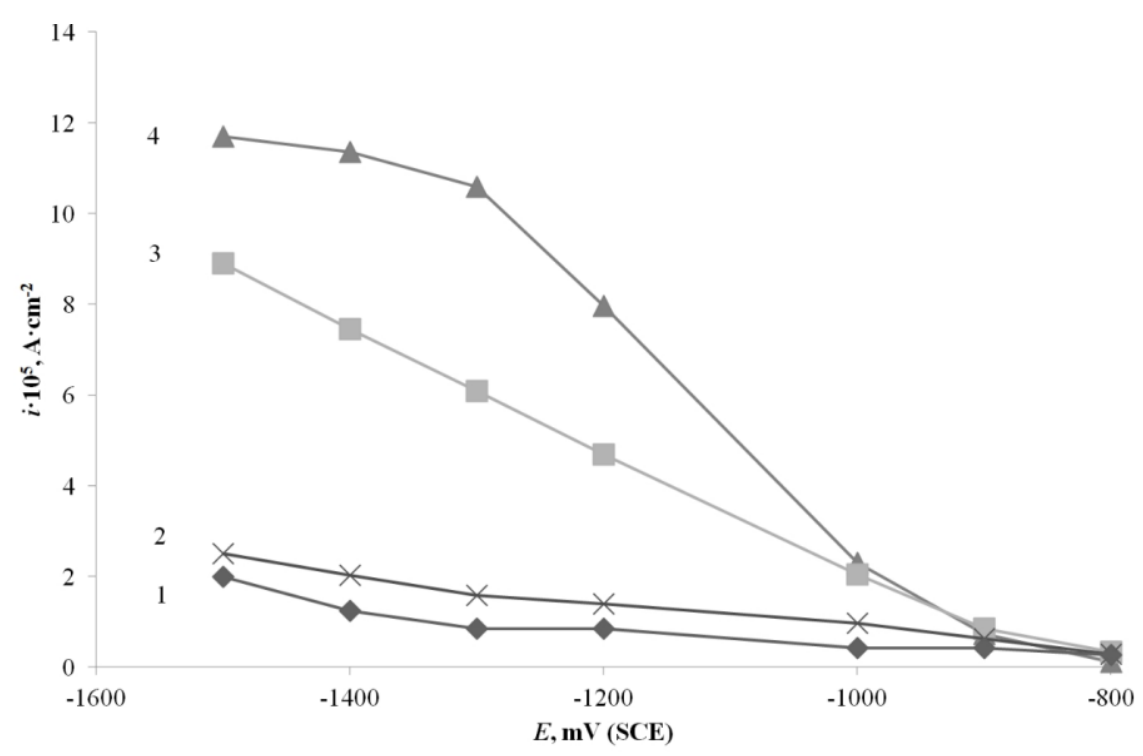

Figure 8. The dependence of the current density of hydrogen penetration on the value of the electrode potential at $\mathrm{pH}$ 6.7: curve 1 - the background; curve 2 - the background $+0.1 \mathrm{M}$ $\mathrm{NaCl}$; curve 3 - the background $+0.1 \mathrm{M} \mathrm{NaCl}+10^{-3} \mathrm{M}$ thiourea; curve 4 - the background + $0.1 \mathrm{M} \mathrm{NaCl}+10^{-4} \mathrm{M}$ thiourea.

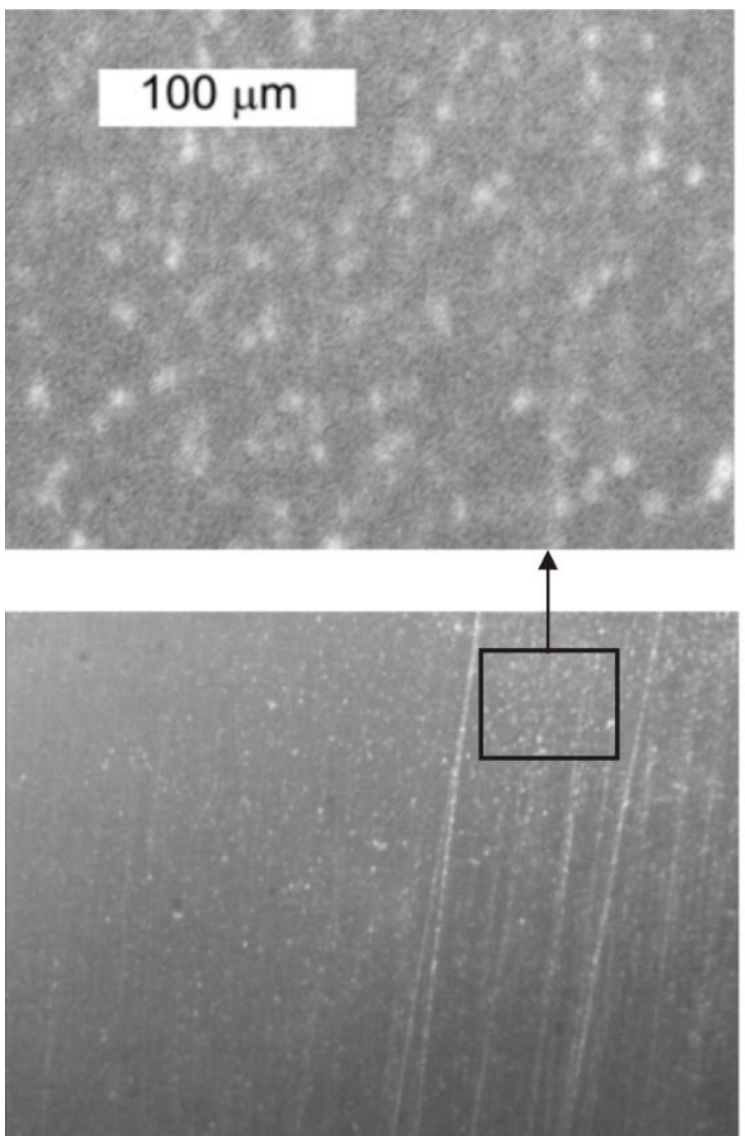

Figure 9. Photographs of samples at a constant potential $E=-1200 \mathrm{mV}, \mathrm{pH}$ 6.7: background solution $+0.1 \mathrm{M} \mathrm{NaCl}+10^{-2} \mathrm{M}$ thiourea. 


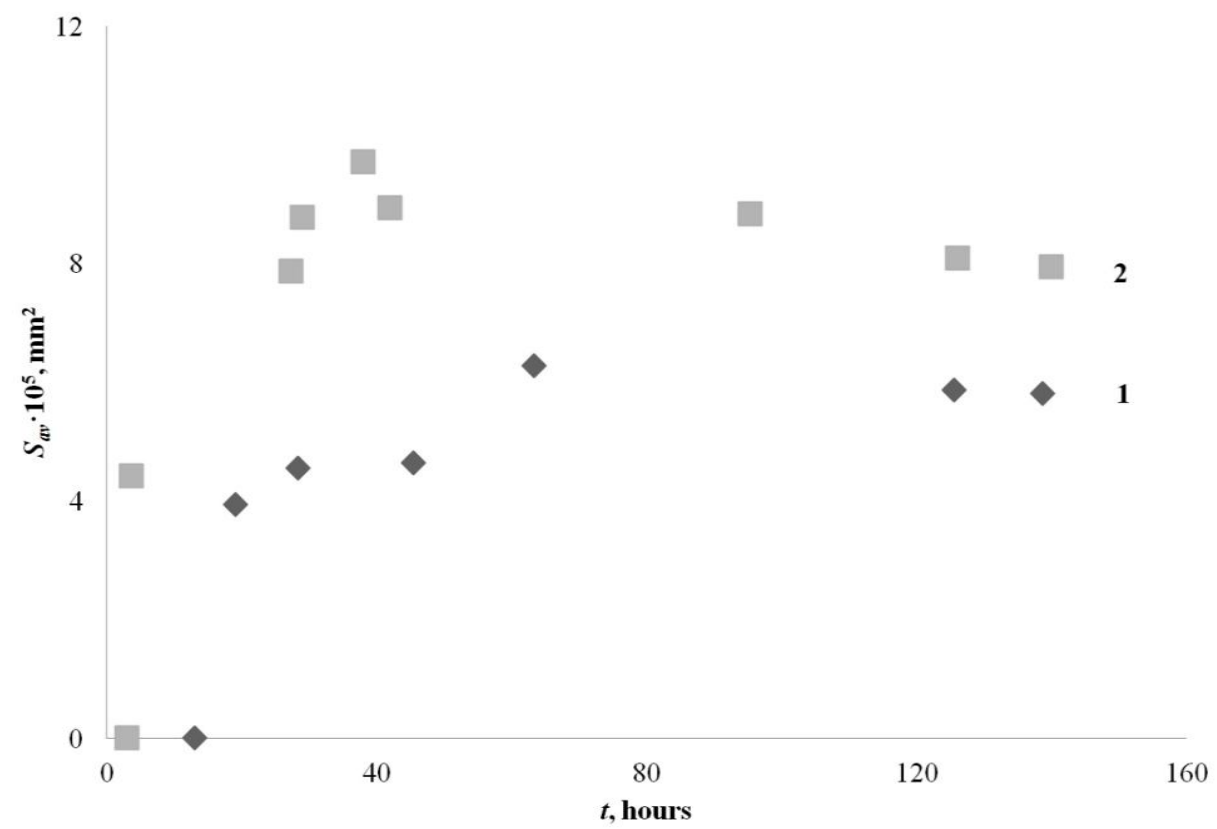

Figure 10. Kinetics of the development of defects with time at $E=-1200 \mathrm{mV}$ in background solution $+0.1 \mathrm{M} \mathrm{NaCl}+$ thiourea $\mathrm{pH} 6.7$ depending on the thiourea concentration: $1-10^{-3} \mathrm{M}$ thiourea; $2-10^{-2} \mathrm{M}$ thiourea.

In Table 2 there are the rates of hydrogen penetration into steel with $E=-1.2 \mathrm{~V}$ in the studied solutions. As it can be seen, the increase in the rate of metal hydrogenation leads to a significant increase in the density of corrosion defects and to a decrease in the duration of the incubation period of their formation. In addition, with an increase in the concentration of the hydrogenation promoter, a faster increase in the area of a single defect is observed (Figure 10); over time, this process slows down, but does not stop completely, as it happened in the background solution with this potential (Figure 6).

Table 2. The rate of penetration of hydrogen into steel $\left(i_{\mathrm{p}}\right)$, the density of filling the metal surface with defects $(\rho)$ and the duration of the incubation period $(I P)$ in solutions of different composition at constant $E=-1.2 \mathrm{~V}$.

\begin{tabular}{cccc}
\hline Composition of solution & $\boldsymbol{i}_{\mathbf{p}}, \mathbf{A} / \mathbf{c m}^{\mathbf{2}}$ & $\boldsymbol{\rho}, \mathbf{d e f e c t s} / \mathbf{m m}^{\mathbf{2}}$ & $\boldsymbol{I P}, \mathbf{h}$ \\
\hline Background & $8.5 \cdot 10^{-6}$ & - & $>150$ \\
Background $+0.1 \mathrm{M} \mathrm{NaCl}$ & $4.7 \cdot 10^{-5}$ & 2.5 & 5.3 \\
Background $+0.1 \mathrm{M} \mathrm{NaCl}+$ & $7.9 \cdot 10^{-5}$ & 20 & 3.7 \\
$10^{-2} \mathrm{M} \mathrm{CH}_{4} \mathrm{~N}_{2} \mathrm{~S}$ & & & \\
\hline
\end{tabular}

Thus, the obtained data confirm that metal hydrogenation contributes to the formation and development of cathodic localized corrosion. 


\section{Conclusions}

The formation of pitting-like defects during cathodic polarization of carbon steel in the presence of chloride ions in the electrolyte was experimentally recorded. It is shown that the dependence of the density of emerging corrosive defects on the potential passes through the maximum, and the time before the formation of the first defect decreases with a negative shift of potential.

It is shown that the dependence of the corrosion defect density on the test time passes through the maximum, what means that some of the arising defects are metastable and cease to function in a few dozens of hours of the experiment.

It is found that the increased rate of hydrogen penetration into the metal caused by the addition of a metal hydrogenation promoter stimulates both the formation and development of a localized defect with cathodic potentials.

The work was financially supported by the Russian Foundation for Basic Research (grants No. 16-08-00445, 17-03-00232).

\section{References}

1. I.V. Strizhevskii, Podzemnaya korroziya i metody zashchity (Underground Corrosion and Protection Metrhods), Metallurgiya, Moscow, 1986, 111 pp. (in Russian).

2. I.V. Strizhevskii, A.D. Belogolovskii, V.I. Dmitriev, V.Yu. Filinovskii and L.I. Freyman, Zashchita podzemnykh metallicheskikh sooruzheniy ot korrozii. Spravochnik (Protection of underground metal structures from corrosion. Handbook), Stroyizdat, Moscow, 1990, 303 pp. (in Russian).

3. M. Schumacher, Seawater corrosion. Handbook, Noyes data corporation, USA, 1979, pp. 27, 48, 55, 57.

4. I.L. Shreir, Corrosion, Newnes-Butterworths, London, 1981, p. 631.

5. K.D. Basiev, A.A. Bigulaev, G.I. Khabalov and E. Dzarukaev, Issledovanie protsessov zarozhdeniya i razvitiya korrozionno-mekhanicheskikh treshchin na poverkhnosti trub (Investigation of the formation and development of corrosion-mechanical cracks on the surface of pipes), Vestnik Vladikavkazkogo nauchnogo tsentra, 2014, no. 3, 56-61 (in Russian).

6. A.B. Arabei, R.I. Bogdanov, V.E. Ignatenko, T.A. Nenasheva and A.I. Marshakov, Effect of corrosion medium composition on rate of crack growth in X70 pipeline steel, Prot. Met. Chem. Phys. Surf., 2011, 47, 236-245 (in Russian).

7. Y.F. Cheng, Stress corrosion cracking of pipeline, pp. 3-5, Wiley \& Sons, Inc., Hoboken, New Jersey, 2013.

8. G. Van Bonen, W. Chen and R. Rogge, The role of residual stress in neutral pH stress corrosion cracking of pipeline steels. Part I: Pitting and cracking occurrence, Acta Mater., 2007, 55, 33.

9. A.I. Zaitsev, I.G. Rodionova, N.I. Endel', K.A. Udod, A.V. Grishin, I.N. Chirkina, I.A. Shumakova and S.Yu. Platonov, Effect of cathodic protection on the development 
rate of corrosion and mechanical damages in the course of laboratory testing the metal of main gas pipelines, Problemy chernoi metallurgii i materialovedeniya, 2012, 4, 6369 (in Russian).

10. Z.Y. Liu, X.G. Li and Y.F. Cheng, Mechanistic aspect of near-neutral pH stress corrosion cracking of pipelines under cathodic polarization, Corros. Sci., 2012, 55, 5460.

11. S.L. Perov and A.V. Sorokin, Technical solutions on increasing the reliability of process pipelines of the fuel gas system station (FGST), Gazovaya promyshlennost', 2017, 747, 68-73 (in Russian).

12. Y.F. Cheng, Stress Corrosion Cracking of Pipelines, John Wiley \& Sons, Inc., 2013, pp. 118, 230-245.

13. T.A. Nenasheva, A.I. Marshakov and I.V. Kasatkina, Obrazovanie lokal'nykh ochagov korrozii trubnoy stali pod deystviem tsiklicheskoy znakoperemennoy polyarizatsii (Formation of local corrosion zones on pipe steel under cyclic alternating polarization), Korroz.: mater., zashch., 2015, no. 5, 9-17 (in Russian).

14. A.I. Marshakov and T.A. Nenasheva, Vliyanie peremennogo toka na skorost' rastvoreniya uglerodistoy stali $\mathrm{v}$ khloridnom elektrolite. Ch. 1. Usloviya svobodnoy korrozii (Effect of alternating current on dissolution rate of carbon steel in chloride electrolyte. Pt. 1. Free corrosion conditions), Korroz.: mater., zashch., 2016, no. 4, 111 (in Russian).

15. A.I. Marshakov, A.A. Rybkina, T.A. Nenasheva and M.A. Maleeva, Vliyanie atomarnogo vodoroda na kinetiku aktivnogo rastvoreniya zheleza. I. Raschet stepeni zapolneniya poverkhnosti zheleza atomami vodoroda i ikh kontsentratsii $v$ poverkhnostnom sloe metalla (Effect of atomic hydrogen on the kinetics of active dissolution of iron. I. Calculation of iron surface coverage with hydrogen atoms and their concentrations in the metal surface layer), Kondensirovannye sredy $i$ mezhfaznye granitsy, 2012, 14, 208 (in Russian).

16. Yu.I. Kuznetsov and M.E. Garmanov, The effect of anions on the kinetics of anodic dissolution and the initial stages of iron passivation in neutral solutions. Borates, Russ. J. Electrochem., 1987, 23, 381 (in Russian).

17. M.E. Garmanov and Yu.I. Kuznetsov, Effect of the scan rate on the kinetic parameters of active dissolution and passivation of iron in a neutral solution, Prot. Met., 2004, 40, 36 (in Russian).

18. M.D. Kononova, V.V. Yudina and V.A. Arutyunyan, Determination of the critical concentration of chlorine ions that initiate ulcer corrosion of carbon steel in neutral aqueous solutions, Prot. Met., 1974, 10, 420-422 (in Russian).

19. M.A. Petrunin, L.B. Maksaeva, D.N. Tyurin and V.A. Kotenev, Scanning electrochemical diagnostics of initial stages of anodic dissolution of carbon steel in chloride containing solutions, Prot. Met. Chem. Phys. Surf., 2008, 44, 529-532 (in Russian). 
20. N.A. Gladkikh, M.A. Maleeva, L.B. Maksaeva and M.A. Petrunin, Izuchenie nachal'nykh stadii lokal'nogo rastvoreniya uglerodistoi stali $\mathrm{v}$ khloridnom rastvore (Study on initial stages of local dissolution of carbon steel in chloride solution), Korroz.: mater., zashch., 2016, no. 6, 17-22 (in Russian).

21. A.I. Marshakov, A.A. Rybkina and T.A. Nenasheva, Vliyanie sorbirovannogo metallom vodoroda na kinetiku aktivnogo rastvoreniya zheleza (Effect of hydrogen sorbed by the metal on the kinetics of active dissolution of iron), Korroz.: mater., zashch., 2006, no. 5, 5-14 (in Russian).

22. B.R. Galvele, Transport processes and the mechanism of pitting of metals, $J$. Electrochem. Soc., 1976, 123, 464-474.

23. A.I. Malkin, A.I. Marshakov and A.B. Arabei, Processy zarozhdeniya i rosta korrozionnykh treshchin na stali magistral'nykh truboprovodov. Ch. 1. Sovremennye predstavleniya o mehanizmakh korrozionnogo rastreskivaniya stalei $\mathrm{v}$ vodnyh sredakh (Processes of initiation and growth of corrosion cracks on major pipelines. Pt. 1. Current concepts of mechanisms of steel corrosion cracking in aqueous media), Korroz.: mater., zashch., 2009, no. 6, 1-15 (in Russian).

24. T.Y. Jin and Y.F. Cheng, In situ characterization by localized electrochemical impedance spectroscopy of the electrochemical activity of microscopic inclusions in an X100 steel, Corros. Sci., 2011, 53, 850-853.

25. M.A.V. Devanathan and Z. Stachurski, The mechanism of hydrogen evolution on iron in acid solution by determination of permeation rates, J. Electrochem. Soc., 1964, 111, no. 5, 619-623. doi: 10.1149/1.2426195

26. M.Z. Yang, J.L. Luo, Effects of hydrogen on disorder of passive films and pitting susceptibility of type 310 stainless steel, J. Electrochem. Soc., 2001, 148, 29-35. 